B. P. Savchuk ${ }^{1}$
ORCID https://orcid.org/0000-0003-2256-0845

I. V. Yehorova ${ }^{1}$

ORCID https://orcid.org/0000-0001-8070-9455

N. O. Fedchyshyn ${ }^{2}$

ORCID https://orcid.org/0000-0002-0909-4424

ResearcherID Q-5422-2016

Scopus Author ID 57202833382

\author{
${ }^{1}$ Vasyl Stefanyk Precarpathian National University \\ ${ }^{2}$ I. Horbachevsky Ternopil National Medical University
}

\title{
FORMATION OF EMOTIONAL INTELLIGENCE OF THE FUTURE MANAGER OF EDUCATION ON THE BASIS OF COACHING TECHNOLOGY
}

\author{
Б. П. Савчук ${ }^{1}$, І. В. Єгорова ${ }^{1}$, Н. О. Федчишин ${ }^{2}$ \\ ${ }^{1}$ Прикарпатський національний університет імені Василя Стефаника \\ ${ }^{2}$ Тернопільський національний медичний університет імені І. Я. Горбачевського МОЗ Украӥни \\ ФОРМУВАННЯ ЕМОЦЙНОГО ІНТЕЛЕКТУ МАЙБУТНЬОГО
МЕНЕДЖЕРА ОСВІТИ НА ОСНОВІ ТЕХНОЛОГІЇ КОУЧИНГУ
}

\begin{abstract}
Analysis of the scientific and theoretical foundations of Emotional Intelligence, psycho-physiological requirements for the training of the future education manager revealed its similarity with the philosophy of coaching. On this basis, the hypothesis is put forward - the formation of Emotional Intelligence, as an important component of the professional competence of future professionals in the field of education, can be effective through the usage of coaching technology. The pedagogical experiment has been organized to test it. Its results are presented in this article.

Key words: Emotional Intelligence; coaching; coaching technology; training of future managers in the field of education; pedagogical experiment.

Анотація. Аналіз науково-теоретичних засад емоційного інтелекту та психофізілогічних вимог до підготовки майбутнього менеджера освіти виявив їхню схожість з філософією коучингу. На цій основі висунута гіпотеза, згідно з якою формування емоційного інтелекту, як важливої складової професійної компетентності майбутніх фахівців у галузі освіти, може бути ефективним на основі використання технології коучингу. Для її перевірки був організований педагогічний експеримент. Його результати представлені в цій статті.
\end{abstract}

Ключові слова: емоційний інтелект; коучинг; коучингова технологія; підготовка майбутніх менеджерів у галузі освіти; педагогічний експеримент.

Introduction. The requirements for professional training of future managers in the field of education have deen increased at the background of the development of the education system in the second half of the XX - early XXI century. Among its modern models (American, European, Australian, etc.), Japanese is highly efficient. It is based on a holistic approach to the formation of a specialist as a whole person. It must meet the requirements of the manager, organizer and high psychophysiological criteria. A high degree of

(C) B. P. Savchuk, I. V. Yehorova, N. O. Fedchyshyn responsibility and emotional stress in relations with the participants in the educational process requires appropriate moral, volitional and physical training of the future specialist. It is manifested in the concept of Emotional Intelligence (EI). It includes such components as emotional restraint, balance, empathy, ability to manage their own emotions, relationships with others.

Subject analysis of scientific and theoretical principles of EI (Bar-On, 2005 [4], Goleman, 1998 [7], Leonard, 1998, Manoylova, 2004, Petrovskaya, 2007, Smith, 
2008 [9],Thorpe, 2008) and psychophysiological requirements for the training of future managers education (Demchuk, 2007 [1], Kolominsky, 2000 [2], Semez, 2011 [3], Fedchyshyn, N.O., \& Yelahina, 2020 [6]) have been found their similarity with the philosophy of coaching (Atkinson, \& Chois, 2009; Cywinska, Majewska, Pepiak-Kowalska, \& Szwec, 2013 [5]; Dilts, 2006, Dobrotvorskiy, 2003, Downey, 2003, Goleman, 1998 [7], ICF Credential, 2012 [8], Leonard, 1998, Parslou \& Rei, 2003, Thorpe \& Clifford, 2003 [10], Zimmerl \& Zimmerl, 2007). On this basis, a hypothesis is put forward. The formation of EI in future education managers can be effective on the basis of coaching technology according to it. The pedagogical experiment has been organized to test it. The results is presented in this article.

The aim - to present the results of a pedagogical experiment to test the hypothesis that the formation of $\mathrm{EI}$ in the future education managers can be effective based on coaching technology.

Theoretical framework. A fairly holistic concept of this phenomenon was formed at the beginning of the XXI century after the appearance of D. Goleman's book "Emotional Intelligence" in 1995. It was described the development of EI theory and defined its basic principles (Goleman, 1998 [7]). Reuven Bar-On made a significant contribution to its development. He developed the EQ-i (Emotional Quotient Inventory) test in 1996. It contains a list of questions to determine its ratio a "Bar-On model" serves on this basis as one of the methodological components of our research. It determines the level of formation of EQ on the basis of a person's possession of 15 abilities: 1) self-esteem awareness and self-assessment of their capabilities and limitations, strengths and weaknesses, self-perception "as I am"; 2) emotional awareness - understanding of emotional state and the reasons for its occurrence; 3) self-expression - a clear, constructive expression of their feelings, thoughts, ability to mobilize emotional energy, show the firmness of beliefs; 4) independence - reliance on their own strength, emotional independence; 5) empathy - recognition, understanding and awareness of the feelings of another person; 6) social responsibility - self-identification as a member of a social group, constructive cooperation, care and responsibility for themselves and others; 7) interpersonal relationships - the establishment of mutually beneficial relationships based on emotional intimacy, comfortable behavior in social contacts; 8) resistance to stress - effective management of their emotions, a quick way out of difficult situations;
9) control of impulses - restraint of emotions; 10) assessment of reality - the comparison of feelings and thoughts with objective reality; 11) flexibility adjustment of feelings, thoughts, ideas, behavior in accordance with circumstances; 12) problem solving finding out the essence and finding ways to solve it effectively; 13) self-actualization - setting goals and striving to achieve it on the basis of potential; 14) optimism - emotional balance, positive attitude and maintaining hope in any situation; 15) happiness / well-being - a sense of satisfaction with others, life in general (Bar-On, 2005 [4]).

A comprehensive analysis of the concept of EI has been carried out while substantiating scientific and theoretical foundations of our experiment. We rely on the synthesized definition of EI as a set of skills and abilities of a personality for recognizing and understanding the emotions, intentions, desires of others and their own, the ability to manage them in the process of practical problems solving (Goleman, 1998 [7]). The concept of EI began to be considered as an alternative to traditional intelligence at the beginning of the XXI century. It reflects the unity of intellectual and affective processes in contrast. This concept encourages and allows to interpret correctly the situation and influence it. It helps to capture intuitively what other people want and need, to acquire knowledge about the strengths and weaknesses of human character; lose personal appeal solving (Smith, 2008 [9]).

In the process of research was found that among the methods and technologies of EI formation. Its conceptual principles are organically consistent with the philosophy and technique of coaching. It has been proven the effectiveness of athletes training (Gelluey T. U., 2010), hence managers, businessmen, teachers other professions.

Leading theorists interpret coaching as: a «vehicle» that helps a person to take the shortest path to a higher level of development, mobilizing their own resources (Dilts, 2006); achieving positive change in the light of mobilization of internal human potential and team activities and a clear organization of the learning process (Atkinson \& Chois, 2009); cooperation focused on self-development of personality via self-reflection of their activities and application of knowledge and skills (Thorpe \& Clifford, 2003 [10]); the process of support, development, strengthening of knowledge and skills with the help of another person (coach) based on the definition of specific goals and objectives, constant reflection and self-reflection, development of new 
patterns of behavior, regular feedback (Coaching, 2013 [5]); built on the principles of partnership, a process that stimulates thinking and creativity of the person and inspires to the maximum disclosure of personal and professional potential (ICF Credential, 2012 [8]).

The core principles of coaching are agreed with the EI settings: people are able to change when they want it and are ready for it; a person's beliefs about his abilities, directly related to achievements; personality himself limits his potential within his own convictions; personality learns with the help of everything he does, but learning occurs only when he thinks and makes plans for the future; a person has much greater inner abilities than those that he realizes in everyday life; learning should be based on success, not mistakes, focus on solving problems, not obstacles; all answers within the pupil, who evaluates himself, seeks and determines the path of development; the absence of a strict expert assessment by the teacher-coach and the imposition of ready-made decisions and instructions.

The analysis of special researches has shown the psychophysiological requirements for the education manager has been agreed with the ideas and principles of EI and coaching. They are manifested in the following skills and abilities: to make optimal decisions and act decisively and effectively in a state of uncertainty and stress; listen and communicate actively and effectively; maintain mental and emotional balance in changing critical situations; to carry out constant self-reflection, self-assessment, self-control; show self-confidence, desire for success, willpower, creative leadership and charisma. A modern education manager should have three groups of fundamental abilities: physical (activity, mobility, energy, strength and health), intellectual (mind, reason, creativity, logical, structural, systematic thinking, intuition), management (persuasive, stimulating skills, motivate, distribute responsibilities and give clear instructions, show tact and tolerance in communication) etc. (Demchuk, 2007 [1], Kolominsky, 2000 [2], Semez, 2011 [3]).

These essential characteristics of EI, coaching and psycho-physiological characteristics of the future education managers are the scientific and theoretical basis of experimental research.

The purpose of the experiment is to develop and test the author's model of EI formation of future education managers on the basis of technological coaching. The experiment has been conducted in four stages with solving the relevant tasks: 1 ) preparatory (development of the experimental activities program; determination of components, indicators, levels of EI formation); 2) ascertaining (diagnostics); 3) formative (introduction into the educational process of coaching technology for the EI formation); 4) control (rediagnosis and determination of the author's model effectiveness).

Vasyl Stefanyk Precarpathian National University (Ivano-Frankivsk, Ukraine) has become the experimental base of the research conducted in SeptemberDecember 2019. The experimental group (EG) of 25 people consisted of undergraduates who received the qualification «Specialists in education management and expertize».

The model for measuring the EI formation level has been developed. It has been integrated four methods for diagnostics: a) measurement of cognitive, personal, motivational components of EI using questionnaires based on self-reports (R. Bar-On) (Bar-On, 2005 [4]); b) EI acmeological examination of teachers and pupils, having based on the principles of selfmonitoring (M. Manoilova, 2004); c) questionnaires compiling to determine the level of culture formation of professional self-education of the future teacher (G. Kodzhaspirova,1994); d) coaching.

The organization and conduct of EG training on the formation of EI were based on coaching methods and techniques GROW, SMART, SMAC, "skill structures", "practice spiral”; "soft" skills; "3D" and others. It provides a definition of the goal and motivation for achieving it; awareness of realities (personal resources, possible obstacles etc.); action planning; selection, search and creation of new resources (methods, forms, means of promotion); monitoring results, selfreflection. The technique of asking "strong" questions is of particular importance. It constitutes the philosophy and methodology quintessence of coaching (Coaching, 2013 [5], Thorpe \& Clifford, 2003 [10]).

A questionnaire was developed to determine the input and output sections of EI formation in EG members at the ascertaining and control stages of the experiment. It consists of 46 questions-statements like: 1 . I always manage to control my feelings, even if I am angry or confused; 2. I am always focused on the feelings of others; 3. I always express my feelings openly in all situations; 4. I pay attention to the emotional state of the person with I communicate; 5. I take into account my feelings in making important decisions; 6 . It is important for me to know how my partner feels when I express emotional support; 7. It is important for me to understand what emotions and feelings led to the conflict; 8. I am indifferent to the feelings and emotions of others arising while working together. 
While working on the questionnaire at the ascertaining stage of the experiment, the members of the EG have evaluated the degree of their agreement with each statement on a 5-point scale. Self-esteem has been formalized in the following meanings: 5 points "always" (feel, understand, can etc.); 4 points "mostly, but not always"; 3 points - "sometimes", 2 points - "occasionally"; 1 - "never".

The questionnaire is divided into 4 sub-scales, which corresponded to 4 EI formation components (self-awareness; self-control; empathy; relationship management). It has 3 integral indices expressing intrapersonal aspect of EI (produced in the process of socialization); interpersonal aspect of EI (formed in the process of learning and professional activity); the total level of EI accumulating the first two indexes. All scales and components are positively interconnected with each other and with the integrated indicator the total EI score. Its internal consistency has been determined on the basis of correlation analysis of the total sample of respondents.

EI indicators have been determined to interpret the diagnostic results on four scales and components. Table 1 presents the general wording of these indicators, due to the limited scope of the article and can't be interpreted at three defined levels (high, medium, low).

Table 1. Indicators for determining the EI formation levels by the main components and scales

\begin{tabular}{|c|c|}
\hline Component and scale & Key indicators \\
\hline $\begin{array}{l}\text { Self-awareness - scale 1: } \\
\text { awareness of personal feelings } \\
\text { and emotions }\end{array}$ & $\begin{array}{l}\text { Development of emotional self-awareness; the need for self-knowledge; adequacy } \\
\text { of self-esteem; development of reflection and intuition; ability to self-reflection, etc. }\end{array}$ \\
\hline $\begin{array}{l}\text { Self-control - scale 2: } \\
\text { Management of own feelings } \\
\text { and emotions }\end{array}$ & $\begin{array}{l}\text { Ability to accept, control, manage the emotions and feelings; ability to use emotions } \\
\text { and feelings for achieving a goal; awareness of psycho-emotional state "here and } \\
\text { now"; development of self-control and tolerance; positivity of thinking; optimism of } \\
\text { perception of oneself, environment, world, etc. }\end{array}$ \\
\hline $\begin{array}{l}\text { Empathy - scale 3: } \\
\text { Understanding the feelings and } \\
\text { emotions of others }\end{array}$ & $\begin{array}{l}\text { Ability to recognize a person's emotions; ability to understand human feelings; } \\
\text { development of social compassion, empathy; ability to sincere emotional } \\
\text { relationships with partners; ability to predict the communication process depending } \\
\text { on the emotional state of the partner, etc. }\end{array}$ \\
\hline $\begin{array}{l}\text { Relationship Management - } \\
\text { scale 4: Influence on the feelings } \\
\text { and emotions of others }\end{array}$ & $\begin{array}{l}\text { Ability to perceive adequately the social environment; ability to manage the } \\
\text { emotional and mental state of the partner; ability to make optimal decisions based } \\
\text { on the interests of their own and others; ability to prevent and resolve conflict } \\
\text { situations effectively; ability to use verbal and nonverbal means of influencing the } \\
\text { interlocutor }\end{array}$ \\
\hline
\end{tabular}

The described prognostic technique has been implemented at the first, ascertaining and third, control stages of the experiment to determine and compare the initial and achieved levels of EI. Levels have been determined in the following intervals: high - from 60 - to 28 points; average - from 27 to - 30 points; low - from 29 to -60 points. At the initial section, the following general state of EI formation has been revealed in EG members by four components: high level - $7 \%$; average level - $65 \%$; low level - $18 \%$. It is proved the feasibility of conducting an experiment to increase the EI of students.

At the second formative stage of the experiment, the author's program for the formation and EI development of future education managers has been tested. Its development is based on: the ideas of T. Leonard, set out in the "Program of Pure Victory"; method of acmeological development of EI by M. Manoilova; integrated experience of coaching techniques and methods usage, set out in the works of its theorists and practitioners (Coaching, 2013 [5], Dilts, 2006; Dobrotvorskiy, 2003, 2003; ICF Credential, 2012 [8]; Landsberg, 2004; Leonard, 1998; Parslou, \& Rei, 2003; Thorpe \& Clifford, 2003 [10] etc.).

Being identified on 4 subscales and 3 EI integral indixes, the functional structure of the author's program consists of two activity blocks "I" and "Others". It determines the vectors of relationships and influences on the main elements of the respective components (Table 2).

The main form of implementation of the author's program have been the coaching training. It has taken place in three stages, the content and methodological tools of the activity blocks "I" and "Others". The tasks of thematic classes have been solved through discussions, exercises and tests, etc. Their general structure and content are presented in table 3. 
Table 2. Functional structure of the author's program of EI formation of future education managers

\begin{tabular}{|l|l|l|}
\hline \multicolumn{1}{|c|}{ Activity blocks } & \multicolumn{1}{|c|}{ Components "I” } & \multicolumn{1}{c|}{ Components “Other” } \\
\hline Awareness & $\begin{array}{l}\text { Self-awareness: } \\
\text { - emotional self-awareness; } \\
\text { - adequate self-esteem; } \\
\text { - self-confidence }\end{array}$ & $\begin{array}{l}\text { Empathy: } \\
\text { - empathy; } \\
\text { - understanding the relationship } \\
\text { "I - You”, “I - They” }\end{array}$ \\
\hline $\begin{array}{l}\text { Self-control: } \\
\text { - the ability to control and manage emotions; } \\
\text { - openness, adaptability; } \\
\text { - focus on the result; } \\
\text { - initiative; } \\
\text { - optimism; } \\
\text { - vigilance }\end{array}$ & $\begin{array}{l}\text { Relationship management: } \\
\text { - promoting change; } \\
\text { - helping people in self-knowledge and self- } \\
\text { development; } \\
\text { - inspiring leadership, influence on the work } \\
\text { of the team; } \\
\text { - conflict resolution, cooperation }\end{array}$ \\
\hline
\end{tabular}

Table 3. Stages and content of coaching training for the implementation of the author's program for the formation of EI of future education managers

\begin{tabular}{|l|l|}
\hline \multicolumn{1}{|c|}{$\begin{array}{c}\text { Stages, blocks and tasks for the } \\
\text { implementation of the author's program }\end{array}$} & \multicolumn{1}{c|}{ Content of classes } \\
\hline $\begin{array}{l}\text { I. Block A: determining the EI level and } \\
\text { planning of EG members' own development; } \\
\text { I. Block B: determining the priorities of } \\
\text { personal development in the process of } \\
\text { interaction with environment }\end{array}$ & $\begin{array}{l}\text { Lesson 1. Goals and objectives of the training. Diagnosis of personal } \\
\text { level of EI. Individual developmental program. } \\
\text { Lesson 2. Cognition of the social environment and interaction with its } \\
\text { subjects }\end{array}$ \\
\hline $\begin{array}{l}\text { II. Block A: implementation of the personal } \\
\text { growth plan; }\end{array}$ & $\begin{array}{l}\text { Lesson 3. Developing skills to realize and regulate emotions. } \\
\text { Lesson 4. Analysis of personal values. Lesson 5. Finding ways and } \\
\text { means to achieve personal goals. Lesson 6. Attitude towards others. } \\
\text { Lesson 7. Interaction with others: reflection, cognition of emotions, } \\
\text { empathy. Lesson 8. Resources to improve communication with the } \\
\text { II. Block B: mastering the knowledge and } \\
\text { skills to understand and influence the emotions } \\
\text { and feelings of others } \\
\text { feelings of others }\end{array}$ \\
\hline $\begin{array}{l}\text { Blocks A and B: determining the achieved } \\
\text { level of EI and prospects for self-development }\end{array}$ & $\begin{array}{l}\text { Lesson 10. Monitoring achievements. Self-development plan: } \\
\text { motivation and identification of own resources }\end{array}$ \\
\hline
\end{tabular}

A system of methods, forms, tools, tasks and exercises are practical experience in organizing training in self-development and personal growth on the basis of coaching. During the training on the EI formation of the future education managers has been adapted and tested (Atkinson \& Chois, 2009; Coaching, 2013 [5]; Dilts, 2006; Dobrotvorskiy, 2003; Downey, 2003; Gelluey, 2010; ICF Credential, 2012 [8]; Leonard, 1998; Parslou \& Rei, 2003; Thorpe \& Clifford, 2003 [10]; Uitmor Dzh., 2005; Uitvord L., Kimsi-Hauz G., \& Sandal F., 2004). We notice the usage of the following typical, original, effective tools:

- task: "Know your emotions and feelings" (its implementation has involved recording in a special table of emotions and feelings that were felt and experienced by members of the EG at a certain time of day, while being performed various activities, as well as the circumstances of their occurrence, caused reactions); "Reflection of values" (choice of life values, thinking about how it will change the lives, determining the practical steps and actions for acquisition);
- techniques for the formation of skills and abilities to concentrate, listening to the interlocutor, relax and meditate, release the brain from control, appeal to "I" (intuition) etc.

- tests: "Workplace ecology"; "Working day organization"; "Taking care of yourself" (determining the mode and nature of physical activity, nutrition, rest, sleep etc.); "Your mental health" (determining the nature of perception of reality, relationships with others, behavior in society under different circumstances); "Your life values and ideals" (ranking and interpretation of basic values and ideals, determining impact on their own behavior and relationships with others);

- questionnaire: "Purpose and goals of life and planning to achieve them";

- mini-trainings: "Matrix of emotional competencies" (monitoring according to the criteria of "deficit", "optimal”, "excess” possession of competencies related to emotional self-awareness, self-confidence, selfesteem, self-control, initiative, openness, adaptability, focus achieving results, optimism, empathy, relation- 
ship and conflict management, inspiring leadership; development of an individual plan for acquisition through self-study, exercise and tasks, self-control); "Influence on another" (work in pairs and mini groups to improve the skills of active listening, focusing, using non-verbal means of communication, adjusting the dialogue); "Managing the emotions of others: feedback" (work in pairs and minigroups to observe and decipher emotional reactions and set to help the interlocutor; involves setting for positive dialogue, empathy, finding convincing arguments and compromise solutions, avoiding accusations, distorted interpretations);

- exercises: "Color and mood" (definition of color according to changes in emotions and mental states; explanation of interdependence); "Relationships with others" (a system of exercises for self-reflection and selfanalysis of the nature of relationships with colleagues, management, customers and behavior in society etc.);

- role-playing games: "Understand the person" (participants are divided into subgroups took turns depicting and guessing emotions and feelings, winning those who have demonstrated them more clearly and guessed faster); "Solve the problem” (participants talk about their real or imagined life difficulties, problems, discuss together and looked for solutions).

Results summarizing of the training has involved the implementation of the members of the EG "Monitoring of personal achievements". It has been formalized in the form of filling in a special table, that is "vertically" pointed the indicators relating to: 1. The existence of personal goals (for several days, months, years); 2. Measures to achieve goals; 3 . Life priorities; 4. Possession of qualities on promoting or inhibiting the achievement of goals (purposefulness; laziness etc.); 5. Mastering the techniques of goal advancing (coaching, others). "Horizontally" on a scale of 5 to 1 points, students have assessed their understanding of the nature and significance of a particular indicator; possession of knowledge and skills of its implementation in practice; practical application etc.

According to the results of the forming experiment, the initial section has been performed and the results of the ascertaining and control experiments have been compared to determine the effectiveness of the author's program. The obtained data is based on the use of the same prognostic tools and is presented in table 4.

Table 4. The results of diagnostics on the main components of determining the EI formation levels of EG members, obtained at the ascertaining ("before” and control ("after") stages of the experiment (in \%)

\begin{tabular}{|l|c|c|c|c|c|c|c|c|}
\hline \multirow{2}{*}{$\begin{array}{c}\text { Component } \\
\text { Levels }\end{array}$} & \multicolumn{2}{|c|}{ Self-awareness } & \multicolumn{2}{c|}{ Self-control } & \multicolumn{2}{c|}{ Empathy } & \multicolumn{2}{c|}{$\begin{array}{c}\text { Relationship } \\
\text { management }\end{array}$} \\
\cline { 2 - 10 } & before & after & before & after & before & after & before & after \\
\hline High & $8 \%$ & $56 \%$ & $4 \%$ & $40 \%$ & $16 \%$ & $72 \%$ & $0 \%$ & $44 \%$ \\
\hline Average & $64 \%$ & $44 \%$ & $52 \%$ & $56 \%$ & $76 \%$ & $28 \%$ & $68 \%$ & $48 \%$ \\
\hline Low & $28 \%$ & $0 \%$ & $44 \%$ & $4 \%$ & $8 \%$ & $0 \%$ & $32 \%$ & $8 \%$ \\
\hline
\end{tabular}

Comparison of the general state of EI formation of EG members by its four components on the output and input sections has revealed that its indicators at a high level increased from 7 to $53 \%$ (7.5 times), on average decreased from 65 to $44 \%$ (in 0,7 times), and at low from 18 to $3 \%$ (6 times). It testifies to the effectiveness of the author's program to increase EI of future education managers. It can be widely used in terms of creative adaptation to the requirements of training specialists in other specialties.

Conclusions and Prospects for Research. Thus, it has been found in the process of research that Emotional Intelligence is an important component of the professional competence of the future education managers and its formation for as a whole person. The conducted pedagogical experiment confirmed the author's hypothesis, according to it the development of
EI of education manageris effective on the basis of the usage of coaching technology. An important basis for this was the agreement of the theoretical foundations of EI and coaching and psycho-physiological requirements for the tourism manager. The author's program was developed on the basis of the creative analysis of the international experience of the organization of training on the basis of coaching has shown the productivity. It is evidenced by a significant increase in the members of the experimental group of the general level of EI formation. The developed prognostic tools for its measurement allow to assert the validity and validity of the experimental results. We believe that the presented experience of experimental work can find wide practical use in the formation of EI of future professionals in various fields of knowledge. In this we see the prospects for further research. 


\section{List of literature}

1. Демчук В. С. Основи освітнього менеджменту : навч. посіб. / В. С. Демчук. - К. : Ленвіт, 2007. - 263 с.

2. Коломінський Н. Л. Психологія менеджменту в освіті (соціально-психологічний аспект) : монографія / Н. Л. Коломінський. - К. : МАУП, 2000. - 286 с.

3. Семез А. А. Менеджмент освіти : навч. посіб. / А. А. Семез. - Кіровоград, 2011. - 168 с.

4. Bar-On R. The Bar-On Model of Emotional-Social Intelligence (ESI) / R. Bar-On // Consortium for Research on Emotional Intelligence in Organizations - Issues in Emotional Intelligence. - 2005. - Access mode : www. eiconsortium.org.

5. Coaching / A. Cywińska, S. Majewska, K. PępiakKowalska, E. Szwec. - Lublin, 2013. - 190 s.

\section{References}

1. Demchuk, V.S. (2007). Osnovy osvitnoho menedzhmentu: navchalnyi posibnyk [Fundamentals of educational management: a textbook]. Kyiv: Lenvit [in Ukrainian].

2. Kolominsky, N.L. (2000). Psykholohiia menedzhmentu $v$ osviti (sotsialno-psykholohichnyi aspekt): monohrafiia. [Psychology of management in education (socio-psychological aspect): monograph]. Kyiv: MAUP [in Ukrainian].

3. Semez, A.A. (2011). Menedzhment osvity: navchalnyi posibnyk [Education management: a textbook]. Kirovohrad [in Ukrainian].

4. Bar-On, R. (2005). The Bar-On Model of EmotionalSocial Intelligence (ESI). Consortium for Research on Emotional Intelligence in Organizations - Issues in Emotional Intelligence. Retrieved from: www.eiconsortium.org.

5. Cywińska, A., Majewska, S., Pępiak-Kowalska, K., \& Szwec, E. (2013). Coaching. Lublin.
6. Fedchyshyn N. O. Peculiarities of future teacher's training at the higher educational establishment / N. O. Fedchyshyn, N. I. Yelahina, N. Ya. Kovtun // Медична освіта. 2020. - № 1. - C. 11-15.

7. Goleman D. Working with emotional intelligence / D. Goleman. - New York : Bantam Books, 1998. - 464 p.

8. ICF Credential - International Coach Federation. 2012. - URL : https://coachfederation.org > icf-credential.

9. Smith M. K. Howard Gardner and multiple intelligences / M. K. Smith // The encyclopedia of pedagogy and informal education. - 2008. - Access mode : https://www. infed.org/mobi/howard-.

10. Thorpe S. Coaching Handbook: An Action Kit for Trainers and Managers / S. Thorpe, J. Clifford. - London : Cogan Page, 2003. - 229 p. - URL : https://www. semanticscholar.org > paper > The-c.

6. Fedchyshyn, N.O., \& Yelahina, N.I. (2020). Peculiarities of future teacher's training at the higher educational establishment. Medychna osvita - Medical Education, 1(86),11-15.

7. Goleman, D. (1998). Working with emotional intelligence. New York: Bantam Books.

8. (2012). ICF Credential - International Coach Federation. URL: https://coachfederation.org > icf-credential.

9. Smith, M.K. (2008). Howard Gardner and multiple intelligences'. The encyclopedia of pedagogy and informal education. Retrieved from: https://www.infed.org/mobi/ howard-.

10. Thorpe, S., \& Clifford, J. (2003). Coaching Handbook: An Action Kit for Trainers and Managers. London: Cogan Page. URL: https://www.semanticscholar.org > paper > The-c.

E-mail address for correspondence: fedushunno@tdmu.edu.ua 